- Nanda Harda Pratama Meiji

Universitas Negeri Malang

\title{
Bergerak di Tengah Banalitas Diskriminasi (Studi Mengenai Kader Anak Muda Dalam Menantang Eksklusivisme di Partai Politik Kota Malang)
}

\begin{abstract}
A B S T R A C T
This paper examines about the dynamics of youth in a political party in Malang, East Java. The proliferation of young people and political parties give us an important picture, especially in the middle of the political situation in Indonesia which is getting negative. Instead of become apathetic, the youth are joined actively in the context of practical politics. A political party that should be an inclusive place for anyone in it (including those of young people) precisely do exclucivity by the others. Some youth who come from minority group especially based on race, class, and gender have experience about discrimination by some people in that party. Using qualitative method with biography approach, there are 3 key informants who will told about their narration related to exclucivity by some people in the political party. Although these youth cadres have experience about racism, class, or gender discrimination, they still seem to be trying to survive and instead fight with in their own way. For these youth the tendency of discrimination must be opposed from within the party because they assume that as a young generation have enough capital to change the future of the party for a better way.
\end{abstract}

Keywords: Youth, political party, and discrimination

\section{Pendahuluan: Kemajemukan yang Rapuh}

Indonesia merupakan Bangsa dengan berbagai macam etnis, kultur, suku, dan agama yang secara kontinu berkembang hingga saat ini. Perkembangan Nusantara sejak era prasejarah hingga kolonial memperlihatkan bagaimana keberagaman yang ada di wilayah Nusantara. Sebagaimana dituliskan pula dalam literatur pada era kolonial oleh J.S. Furnivall dimana masyarakat pada masa tersebut memiliki berbagai macam etnis, agama, dan identitas yang saling berbaur meskipun tanpa menjadi satu kesatuan yang utuh dan dikategorikan sebagai masyarakat majemuk (dalam Coppel,
1997). Demikian pula dalam beberapa tulisan karya Lombard juga memperlihatkan kemajemukan masyarakat di era kolonial. Dalam bukunya Nusa Jawa Silang Budaya, Lombard mampu memberikan gambaran dimensi kemajemukan masyarakat di wilayah Pulau Jawa yang terdiri dari perpaduan berbagai macam etnis dan budaya dari penjuru nusantara bahkan dunia (2000). Hal tersebut memperlihatkan bahwasanya kemajemukan di Indonesia/Nusantara tidaklah muncul tiba-tiba tetapi muncul dengan dimensi yang berbeda sesuai sudut pandang historisitasnya, namun keberagaman tersebut dalam satu sisi justru 
memunculkan persinggungan yang menjadi sebuah kedok dalam konflik-konflik ekerasan komunal. Sebagaimana diutarakan dalam novel karya Pramodya Ananta Toer dalam Arus Balik dimana kedigdayaan agama baru berusaha untuk menghilangkan aspek agama/tradisi sebelumnya (2001). Namun rupanya bukan hanya di era masa itu saja, konflik kekerasan komunal justru bermunculan terutama paska reformasi (Klinken, 2007; Lay, 2009). Konflik kekerasan tersebut kian merebak terutama pada masa runtuhnya rezim orde baru. Tidak dapat dipungkiri bahwa persoalan kesetaraan dan kesenjangan ekonomi yang tak kunjung selesai sejak era Orde Lama hingga Orde Baru dan kemudian dibalut oleh agama dan etnisitas justru makin membuat konflik makin langgeng.

Hal tersebut dapat disaksikan dalam kajian kekerasan yang disampaikan oleh yang menggambarkan bagaimana etnis Tionghoa mengalami diskriminasi dan bahkan kekerasan simbolik maupun fisik (Banurea, 2015). Atau kekerasan yang terjadi di Sampit dan juga Maluku dimana unsur etnisitas dan agama menjadi kedok di balik tragedi berdarah yang terjadi (Patji, 2003; Trijono, 2001).

Tidak lupa pula dalam ingatan sejarah, bahwasanya partai politik memberikan peran mereka dalam proses demokrasi di Indonesia sejak masa pergerakan nasional hingga masa reformasi. Hal ini seperti ditunjukkan pada era pergerakan nasional hingga masa reformasi oleh PRD yang digawangi oleh Budiman Sudjatmiko ataupun PDI-P pimpinan Megawati dan juga PKB yang dikelola oleh Abdurrahman Wahid. Gerakan untuk melakukan proses pergantian kekuasaan pada Orde Baru menjadi salah satu momentum perubahan yang ada di Indonesia. Oleh sebab itu partai politik hingga saat ini sebenarnya masih memegang peranan penting terutama sebagai agen perubahan sekaligus penjaga kemajemukan di tanah air.

Dalam kontestasinya tidak hanya mengandalkan sistem kepartaian semata namun juga agen/kader yang ada di dalam partai itu sendiri. Terlebih lagi menyangkut proses regenerasi partai dimana anak-anak muda memiliki peran untuk menjaga ideologi serta kebesaran partai. Namun rupanya bagi beberapa anak muda yang berasal dari kalangan minoritas alih-alih mendapatkan perlakuan yang setara justru terkadang mengalami diskriminasi dari segi etnisitas maupun identitas. Pada konteks keseharian mereka masih mengalami diskriminasi dari rekan-rekan mereka. Rupanya masih terjadi kegagapan di dalam tubuh partai itu sendiri. Terlebih bagi anak-anak muda yang cukup produktif justru semakin mengalami diskriminasi dan sindiran dari rekan sejawatnya di partai politik.

Dinamika yang muncul berbeda dari wacana yang digaungkan oleh partai politik sebagai salah satu penjaga kemajemukan bangsa dalam konteks demokratisasi di Indonesia. Alih-alih menjadi agen penjaga kemajemukan nasional, rupanya masih terdapat oknum-oknum kader yang justru mendiskriminasikan rekan kader lain (terutama bagi mereka yang berasal dari kalangan minoritas). Hal ini yang kemudian menarik saya untuk melakukan kajian lebih lanjut untuk melihat bagaimana kemajemukan di tubuh partai tersebut berlaku dalam keseharian.

\section{Metode Penelitian}

Dalam penelitian kali ini saya menggunakan metode kualitatif dengan pendekatan life story. Mengutip penjelasan 
life story yang diutarakan oleh Bertaux bahwasanya kisah hidup seseorang memiliki keterkaitan dengan masa kini (1988:7-9). Pun demikian yang diutarakan oleh Mannheim bahwasanya historisitas yang lalu penting untuk melihat kontinuitas perjalanan hidup seseorang (1952:287-288). Narasi yang dijelaskan oleh para informan menjadi penting terutama bagi saya untuk melihat secara berkelanjutan perjalanan kehidupan informan tersebut.

Pengumpulan data saya lakukan pada kisaran tahun 2014 di masa pemilu legislatif dan presiden. Pada saat itu saya melakukan kajian riset mengenai anak muda yang bergabung ke dalam partai politik di Kota Malang. Namun kemudian untuk pembaharuan data, saya kembali melakukan wawancara mendalam pada beberapa bulan terakhir kepada 3 informan utama terutama terkait bagaimana mereka tumbuh sebagai etnis minoritas yang mengalami diskriminasi dalam kesehariannya. Ketiganya tergabung sebagai anggota salah satu partai terbesar yang ada di Kota Malang. Rerata usia mereka juga masih dalam kategori pemuda apabila menggunakan definisi pembatasan UU Kepemudaan yakni 17-30 tahun.

Tidak mudah bagi mereka ketika menceritakan pengalaman pribadi kepada orang lain. Bagi anak-anak muda ini narasi yang mereka alami dan paparkan satu sisi merupakan sebuah aib bagi mereka. Tabu yang dikonstruksi oleh mayoritas pada tatanan minoritas di masyarakat. Namun pada sisi yang lain hal tersebut merupakan kebanggaan bagi mereka karena berusaha menampilkan jati diri mereka sebagai bagian di dalam minoritas. Hal tersebut dipaparkan dalam narasi Santi sebagai perempuan dari kelas ekonomi bawah yang masih berada di dalam budaya patriarki. Kemudian Rio yang lahir dalam silsilah etnis Tionghoa dan juga
Tomi yang juga lahir sebagai etnis Madura dimana terdapat stereotype negatif dalam masyarakat. Oleh sebab saya kemudian berusaha mengangkat narasi ketiganya yang hidup di dalam dunia masyarakat yang rupanya masih ekslusif terlebih pada kalangan minoritas. Selain itu alam tulisan kali ini saya akan berusaha untuk memaparkan pula bagaimana partai politik yang menjadi ranah sekaligus sarana inklusivitas bagi anak-anak muda tersebut justru menampilkan keeksklusifan di dalam ras, jender, dan kelas.

\section{Narasi Anak Muda di Partai Politik}

\section{Santi}

Besar di lingkungan keluarga dengan tingkat ekonomi rendah membuat Santi terbiasa dengan kehidupan serba pas-pasan. Perempuan kelahiran 1991 ini adalah anak bungsu dari 3 bersaudara. Santi lahir di salah satu wilayah perkampungan padat penduduk yang ada di Kota Malang. Bapak dan Ibunya membanting tulang demi menghidupi ketiga orang anaknya. Bapak Santi dulunya merupakan tukang becak, namun seiring berjalannya usia, kekuatan fisiknya mulai melemah dan kemudian beralih profesi membuat mainan kuda lumping untuk diperjualbelikan di sekitar Malang. Sementara itu Ibunya membuka warung kelontong di rumahnya dan kadang berjualan gorengan sebagai tambahan modal ekonomi keluarga. Kedua kakaknya masing-masing telah berkeluarga dan bekerja di Bali dan Malang.

$$
\text { Perjalanan pendidikan Santi }
$$
seperti halnya anak-anak pada umumnya sekolah di sebuah SD dan 
SMP negeri di sekitar wilayahnya. Baru ketika masuk pada tingkat berikutnya, Santi lebih memilih untuk masuk SMK daripada SMA. Hal ini karena bagi Santi SMK lebih menawarkan dunia praktek kerja dimana setelah lulus, ia dapat langsung masuk dalam dunia kerja. Masa transisi yang dilalui oleh Santi rupanya relatif berjalan sederhana dan penuh lika liku. Meskipun demikian terbukti setelah lulus, berkat kegigihan dan keuletannya selama masa magang, membuat Santi memperoleh pekerjaan di sebuah kantor konsultan pajak. Ilmu akuntansi yang ia peroleh selama masa SMK rupanya cukup dibutuhkan di kantor tersebut. Setelah setahun bekerja dan mengumpulkan uang, Santi dapat meneruskan pendidikannya di sebuah universitas swasta yang ada di Kota Malang. Pilihan pada universitas swasta tersebut agar ia mampu mengatur waktu pendidikannya sembari tetap bekerja. Meskipun kemudian pada tahun 2013 Santi akhirnya memutuskan untuk keluar dari pekerjaannya di kantor notaris tersebut dan beralih menjadi guru PAUD (Pendidikan Anak Usia Dini). Namun rupanya di tahun yang sama Santi malah mendapatkan tawaran pekerjaan yang lebih menarik di sebuah biro perjalanan pariwisata. Hingga saat lulus kuliah tahun 2015 sampai saat ini Santi tetap melanjutkan karirnya di biro wisata tersebut karena lebih menjanjikan secara finansial.
"Sebenernya memang susah ya Mas kalau udah bicara masalah uang. Soalnya gimanapun aku juga orang yang mungkin pragmatis. Jadi dimana ada rezeki yang lebih lancar ya aku akan lebih memilih kesana. Apalagi kerjaanku sekarang di biro wisata bukan hanya oke secara finansial tapi juga sosial. Jadi aku benarbenar merasakan apa yang tak suka dan pekerjaan jadi satu ya disini ini" (Wawancara September 2017)

Santi awalnya tidak ingin untuk bergabung dengan partai politik. Awalnya bagi Santi partai politik tidak memberikan pengaruh signifikan dalam kehidupannya. Keikutsertaanya pada partai politik lebih karena desakan lingkungan sekitarnya terutama karena wilayahnya merupakan salah satu basis massa salah satu partai terbesar di wilayah Kota Malang. Kebutuhan terhadap seorang sekretaris yang mumpuni di wilayah ranting, membuatnya akhirnya mau untuk bergabung dengan partai. Terlebih rupanya warga tidak hanya menekan Santi tapi juga kedua orangtuanya. Konteks sekretaris sendiri masih dalam konsep yang bias jender dimana seorang sekretaris seyogyanya adalah perempuan. Sementara perempuan yang aktif dan mau terlibat dalam keorganisasian partai masih jarang terlebih di tingkat ranting.

"Ya gimana ya Mas, aku gabung sama partai sekarang ini lebih karena desakan warga kampung yang butuh orang untuk kerjaan ketik mengetik. Kalau yang ditekan 
cuma aku nggak apa Mas, tapi ini bukan cuma itu tapi juga intimidasi ke Orangtuaku. Aku gimana pun nggak mau Orangtuaku diapa-apain Mas." (Wawancara Mei 2014)

Keikutsertaannya pada parpol ini pula yang kemudian mengantarkan jejak Santi untuk menjadi salah satu caleg bahkan yang termuda pada pemilu legislatif 2014 lalu. Meskipun mendapatkan banyak pengalaman yang kurang menyenangkan pada masa pemilu legislatif 2014 lalu, terutama bagaimana ia mengalami diskriminasi di lingkungan partainya, Santi rupanya masih tetap bertahan di parpol. Segala macam berita hoax mengenai dirinya diacuhkannya meskipun masih sakit hati karena berbagai gosip yang Santi mengungkapkan kesediaannya untuk tetap di partai politik bukan tanpa alasan. Bagi Santi pada akhirnya ia memiliki keyakinan untuk bisa mengubah bagaimana paradigma partai terutama pada sosok perempuan muda seperti dirinya. Santi mengungkapkan bahwasanya ketidakadilan yang ia alami justru menjadi pelecut bagi dirinya untuk tetap melanjutkan karir perpolitikkannya. Santi menjelaskan bahwa untuk melakukan perubahan itu tentunya ia harus tetap bergelut dengan dunia perpolitikan di partai dan mendapatkan jabatan strategis.

"Sekarang aku mau coba fokus di kerjaanku sama partai Mas. Aku pribadi mau membuktikan kalau seorang Santi yang perempuan dari keluarga kampung bisa mengubah cara pandang orangorang itu. Bukan sekedar untuk dapat pengakuan Mas tapi lebih ke arah supaya mereka nggak lagi menyepelekan dan menghina perempuan" (Wawancara September 2017)

\section{Rio}

Rio adalah salah satu anak muda yang memiliki garis keturunan Tionghoa di partai. Meskipun berasal dan besar di keluarga kelas menengah atas, bagi Rio hal tersebut belum cukup terutama untuk ajang aktualisasi dirinya. Pria yang lahir 30 tahun yang lalu ini baru saja menyelesaikan studi pendidikan tingginya di jurusan ilmu politik di salah satu universitas negeri yang ada di Kota Malang pada tahun 2016. Pilihannya pada bidang politik juga tidak dialaminya secara tiba-tiba. Sebagaimana Santi, Rio pun memiliki perjalanan transisi yang berliku sebelum pada akhirnya mengambil karir politik sebagai salah satu langkah hidupnya.

Kedua orangtua Rio merupakan pengusaha yang cukup sukses di zamannya, meskipun kemudian akhirnya mesti berpisah. Rio pun akhirnya dibesarkan oleh Ibunya hingga dewasa. Konflik kerusuhan di Indonesia pada periode 90an rupanya turut mengusik ketenangan keluarga Rio. Meskipun sang kakek merupakan pensiunan tentara pada masa tersebut, hal itu tidak membuat keamanan keluarga Rio tenang. Hingga akhirnya sang Ibu dan keluarga besar beserta Rio pindah untuk sementara waktu ke Singapura dan kemudian ke Amerika Serikat. Kurang lebih selama satu tahun Rio dan Ibunya menghabiskan waktu di Amerika dan menunggu keadaan politik di Indonesia membaik. 
"Ya waktu reformasi 1998 dulu saya sama Mama pergi Mas ke Amerika, untuk menghindar sejenak dari kerusuhan di Indonesia, apalagi kan saya ada keturunan Tionghoa juga Mas. Jujur itu nggak tahu harus senang atau sedih sih Mas. Senang karena bisa ke luar negeri, tapi di sisi yang lain sedih karena mesti kabur dari negeri sendiri" (wawancara Juli 2014)

Setelah kembali dari Amerika, Rio melanjutkan kembali pendidikannya di sebuah SD hingga SMP negeri. Di periode berikutnya Rio memilih untuk masuk di SMK dengan spesialisasi perhotelan dimana ia beranggapan hal tersebut nantinya akan berguna untuk melanjutkan bisnis keluarga besarnya. Namun rupanya paska lulus SMK, Rio lebih memilih untuk melanjutkan karirnya di bidang seni perfilman di IKJ (Institut Kesenian Jakarta). Namun mendapatkan banyak ketidaksetujuan terutama dari Ibunya. Rio pun nekad ke Jakarta dengan dalih belajar dan membantu bisnis perhotelan keluarga besarnya yang ada di Ibukota. Namun di sela waktunya tersebut rupanya Rio juga mengikuti casting film pendek dan bahkan mendapatkan peran sebagai figuran di beberapa FTV. Impiannya untuk masuk ke IKJ pun sirna lantaran biaya yang ia kumpulkan tidak mampu untuk mencukupi kebutuhan pendidikannya tersebut. Alhasil Rio pun kembali ke Kota Malang dan membantu bisnis fitness Ibunya. Di masa tersebut Rio kemudian terpikir untuk mencoba masuk perkuliahan di jurusan Ilmu Politik, sebuah ilmu yang sebenarnya ia kagumi terutama paska dimana ia harus berpindah ke Negara lain hanya karena seorang warga keturunan. Bagi Rio hal tersebut muatannya lebih politis sehingga ia ingin mencoba mendalaminya. Sebuah momen yang kontras bagi Rio dan tentunya lagi-lagi hal tersebut mendapatkan penolakan dari Ibu dan keluarga besarnya. Namun kali ini ia mampu meluluhkan hati Ibunya dan mendapatkan izin untuk kuliah pada jurusan tersebut.

Di masa perkuliahan tersebut Rio tidak hanya ingin mendapatkan pendidikan politik di jalur akademis, Ia juga mencoba untuk memilih karir politik via jalur partai. Hingga akhirnya bersamaan dengan ketika dia diterima menjadi mahasiswa, Rio juga mendaftarkan dirinya di partai dimana ia sekarang berada. Bagi Rio awalnya hal ini ia lakukan untuk lebih mendalami karir perpolitikkannya kelak. Seiring perkembangannya Rio menjadi salah satu kader muda yang cukup disegani karena kemampuan politiknya. Hal tersebut terbukti di mana ia mampu menjadi ketua organisasi kepemudaan di partai tersebut. Bahkan saat ini setelah lulus Rio mendapatkan pekerjaan sebagai asisten ahli dari salah seorang anggota DPRD tingkat provinsi.

Meskipun demikian rupanya masih terdapat beberapa oknum kader di partai yang kurang simpatik dengan Rio terutama kaitannya dengan rasisme. Hal tersebut beberapa kali saya temukan ketika melakukan observasi di kantor DPC, beberapa kader menggunjing kinerja Rio namun dalam bahasan yang lebih rasis dimana menyangkut pautkan dengan garis silsilah keturunan dan 
agamanya. Rio pun tidak memungkiri bahwasanya terkadang ia mendengar selentingan semacam itu. Namun Rio lebih memilih untuk acuh karena baginya hal tersebut juga terjadi bukan hanya di partai politik tapi juga masyarakat umum dimana masalah rasisme pada orang keturunan Tionghoa sudah jamak dibicarakan. Rio lebih jauh juga mengungkapkan salah satu alasan terbesarnya untuk bergabung di partai politik adalah selain untuk karir politik, ia juga menjelaskan bahwasanya berusaha untuk menghilangkan ekslusivitas terutama pada warga keturunan bukan hanya di partai tapi juga di masyarakat. Terbukti kini Rio mampu menjadi staf ahli dari salah seorang anggota DPRD Provinsi karena kemampuannya.

"Ya gimana lagi Mas kalau saya terserah mereka mau ngomongin apa tentang saya termasuk kalau ngomong tentang identitas keturunan saya yang berbeda dengan mayoritas. Tapi saya mau buktiin Mas meskipun saya bukan berasal dari mayoritas tapi saya juga qualified di partai politik. Jadi saya akan buktikan dengan kerja dan hasil nyata Mas. Saya mau buktikan kalau sebagai warga keturunan pun juga sama-sama orang Indonesia yang punya hak dan kemampuan sama dengan lainnya."(Wawancara September 2017)

\section{Tomi}

Tomi merupakan anak muda yang besar di lingkungan cukup keras sepanjang hidupnya. Lahir di keluarga dengan ekonomi rendah membuatnya seperti halnya Santi bekerja keras sejak anak-anak hingga saat ini. Sejak kecil
Tomi berpindah-pindah dari satu kota ke kota yang lainnya mengikuti kedua Orangtuanya yang nomaden. Lahir di Madura, namun Tomi mengakui bahwa kehidupannya yang berpindah-pindah menempatkannya dalam kultur yang majemuk. Setidaknya 5 kota telah ia lalui bersama keluarganya hingga saat ini dan akhirnya menetap di Malang. Bapak Tomi memiliki pekerjaan yang berubah-ubah, mulai dari kuli bangunan, tukang becak, pengumpul besi tua, hingga tukang parkir. Sementara Ibunya hanya seorang ibu rumah tangga yang harus merawat ia dan 4 saudaranya yang lain. Oleh sebab itu Tomi telah terbiasa dengan kerasnya kehidupan di masyarakat. Terlebih lagi sebagai seseorang yang lahir dengan identitas Madura, Tomi kerap mengalami diskriminasi dimana lingkungannya kerap memberikan stereotype negatif pada dirinya. Sebagaimana dijelaskan bahwasanya orang Madura memiliki stereotype sebagai etnis yang keras, kaku dan cenderung menakutkan (Bustami: 2014; Rochana, 2012).

Jalur pendidikan yang dilalui Tomi juga penuh lika liku dimana ia sempat harus berhenti sekolah karena kurangnya biaya selama satu tahun. Namun berkat kesigapannya dalam mencari tambahan uang, Tomi akhirnya mampu tetap melanjutkan pendidikannya hingga tingkat sekolah menengah atas. Tomi merasa ragu untuk mengambil hingga tingkat pendidikan tinggi karena selain faktor biaya yang cukup tinggi juga baginya pendidikan tinggi tidak menjaminnya untuk mendapatkan pekerjaan. Oleh sebab itu paska lulus SMK, Tomi 
kemudian melanjutkan kerja di sebuah toko sebagai pegawai. Tidak berjalan lama, Tomi merasa beban pekerjaannya dengan upah yang ia dapatkan kurang mumpuni. Alhasil ia pun mencoba beberapa pekerjaan seperti menjadi kenek truk dan terakhir saat ini bertugas sebagai tukang parkir di salah satu jalan padat di kawasan Kota Malang.

Keterikatannya di partai politik juga terbilang baru untuknya. Awalnya Tomi tidak terlalu tertarik untuk bergabung di dalam sebuah partai. Baginya partai tidak terlalu penting di dalam kehidupannya. Namun rupanya karena beberapa teman dekatnya ikut tergabung dalam partai politik, ia kemudian ikut pula. Pengaruh temantemannya rupanya membuat Tomi berubah pandangan dan ikut menjadi salah satu kader partai politik.

\section{"Awalnya ya nggak tertarik Mas sama politik-politik itu. Ngapain mau ikut partai begituan toh nggak bawa hasil apa-apa buat saya? Tapi akhirnya ikut ya gara-gara teman-teman banyak yang ikut Mas pas mau pilkada Kota Malang itu. Jadi ya sudah dicoba aja dulu dan ternyata setelah tak jalani asyik Mas dapat banyak ilmu."(Wawancara Mei 2014)}

Keikutsertaannya di partai membuatnya perlahan mengerti mengenai konteks perpolitikan terutama di ranah Kota Malang. Bagi Tomi rupanya partai politik membuatnya semakin paham terutama terkait ketimpangan sosial yang ia alami. Bagi Tomi yang tidak pernah mendapatkan ilmu terkait perpolitikan dan ilmu sosial masyarakat, beberapa kegiatan workshop di DPC membangkitkan kesadarannya bahwasanya masih banyak masalah di Indonesia. Berawal dari sana, Tomi kemudian beberapa kali kerap bertanya dan berdiskusi terkait masalah-masalah sosial yang ada di Indonesia. Hal ini yang kemudian rupanya yang kemudian akhirnya membuat jarak antara dia dengan beberapa temannya. Menurut penuturan Tomi, temantemannya banyak yang enggan untuk diajak berdiskusi atau mengobrol mengenai hal tersebut. Berbeda dengan Tomi yang cukup antusias dan biasanya sengaja untuk meluangkan waktu di kala diadakan kegiatan diskusi atau workshop, temantemannya cenderung pasif bahkan tidak hadir dalam beberapa kegiatan.

Bahkan saat saya melakukan observasi, beberapa teman Tomi sedang menggunjing Tomi akibat terlalu keminter (dianggap sok tahu). Dalam obrolan tersebut Tomi dianggap tidak pantas untuk sok politik karena bagi mereka Tomi layaknya mereka yang berasal dari ekonomi kelas bawah dan berasal dari etnis yang berbeda. Saat saya mengobrol dengan teman-teman Tomi, mereka mengungkapkan bahwasanya tidak penting bagi mereka untuk tahu atau paham mengenai konteks sosial politik di masyarakat, karena toh tidak akan membawa dampak apapun bagi mereka. Sementara mereka hanya menjadi penggerak pemilih di beberapa wilayahnya masing-masing yang (lagilagi) bagi mereka hanya mengandalkan untuk dicari potensi suara di masyarakat. Jadi seolah-olah mereka tak lebih dari pencari suara bagi partai.

Hal yang bertolak belakang dengan pendapat Tomi dimana baginya meskipun ia juga menjadi penggerak pemilih dan mendapatkan bayaran dari para caleg, tapi Tomi berusaha untuk mendukung caleg yang ia yakini akan membawa perubahan bagi masyarakat. 
Karena ketertarikannya konteks tersebut yang kemudian membuat Tomi terkucilkan karena dianggap oleh teman dan kader lainnya sebagai "orang kecil yang sok tahu". Terlebih lagi unsur etnisistas yang melekat pada dirinya yakni sebagai orang Madura dimana stereotype acuh dan menang sendiri kerap melekat pada dirinya. Namun Tomi seakan mengacuhkan stereotype tersebut dan berusaha untuk membuktikan bahwasanya meskipun tidak memiliki modal ekonomi dan pendidikan yang cukup, ia mampu untuk berpolitik praktis di ranah partai. Meskipun sempat pula mendapatkan penolakan untuk memegang suatu acara hanya karena ia dianggap kurang memiliki modal ekonomi untuk mempertanggungjawabkan acara tersebut, namun Tomi mengisyaratkan tetap bertahan di partai dan berusaha meningkatkan potensi yang dimiliki untuk tetap bersaing di dalamnya.

\section{Kontestasi Politik di Masa Pemilu}

Lantas bagaimana dengan kontestasi politik mereka selama ini di partai politik? Tentunya sebagai bagian dari minoritas, Santi, Tomi, dan Rio merasa terusik karena identitas yang melekat pada diri mereka terusik. Sebagaimana pada tahun 2014 di kala mereka membantu para caleg dari partai mereka untuk memenangkan pileg 2014. Bukan hanya sekedar membantu meningkatkan popularitas partai di masyarakat, pada kesempatan pemilu 2014, digunakan oleh Santi, Tomi, dan Rio untuk mengunggulkan diri mereka pada senior mereka dan juga masyarakat khalayak umum. Sebagaimana partai yang lain, partai politik yang menaungi ketiganya juga turut andil dalam gegap gempita pesta demokrasi. Para kader, khususnya caleg saling berlomba satu sama lain untuk meningkatkan popularitasnya sekaligus partai pada masyarakat umum, khususnya guna memperoleh suara pada masa pencoblosan (Meiji, 2016). Di sini peran anak-anak muda tidak kalah penting baik untuk meningkatkan popularitas caleg maupun partai.

Santi pada masa pemilu legislatif 2014 bahkan menjadi seorang caleg termuda di kala itu. Meskipun dengan kondisi "dipaksakan" oleh mekanisme partai, Santi rupanya juga masih mampu meraup sejumlah suara. Selama pemilu legislatif berlangsung, Santi yang mulanya acuh pada proses kampanye, perlahan mulai peduli. Kenapa hal ini terjadi? Menurut penuturannya, meskipun ia hanya sekedar menjadi "alat" bagi partai untuk pemenuhan kuota perempuan, nyatanya ia juga memperoleh fitnah selama pemilu legislatif 2014 berlangsung. Salah satu berita miring mengenai Santi adalah ia merupakan gadis simpanan dari salah seorang caleg. Hal tersebut tentunya kemudian membuat Santi kelabakan karena ia takut apabila berita-berita seperti itu sampai ke telinga kedua orangtuanya. Santi memang mengaku memperoleh sejumlah dana kampanye dari beberapa orang caleg di partainya namun hal tersebut sesuai dengan kesepakatan yang dibuat yakni sebagai ganti biaya Santi karena dilibatkan sebagai caleg perempuan di dapilnya.

"Awale itu aku ya kurang gimana gitu Mas sama yang namanya pencalonan caleg ini. La kan emang sejak awal juga kepaksa to Mas ikut partai ini. Jadi pas ada proses penyaringan dan seleksi caleg itu, aku disuruh untuk ikut. Jadi mulai dari kader di Polehan (wilayah tempat tinggalnya) sampai di Blimbing (wilayah dapil) maksa aku supaya mau jadi caleg. Awalnya ya nggak mau Mas 
karena pasti capek harus urus berbagai hal dan itu membuang waktu juga tenagaku. Belum lagi nanti kan kalau jadi caleg butuh biaya berapa untuk masalah administrasi dan kampanye. Tahu sendiri Mas, saya nggak punya uang sebanyak itu untuk hal-hal kayak begini. Akhirnya aku terima tawaran jadi caleg itu setelah ada orang yang mau membiayai seluruh pengeluaran dari awal hingga akhir kampanye. Selain itu aku juga nggak ingin nanti kalau aku menolak bakalan ada apa-apa sama Bapak Ibu Mas kayak kejadian di ranting sebelumnya" (wawancara Mei 2014)

Demikian pula dengan apa yang dilakukan oleh Tomi dan Rio di kala pemilu legislatif 2014. Berbeda dengan Santi yang "terjebak" dalam proses pencalegan, mereka juga turut andil untuk menjadi anggota tim sukses dari caleg-cleg senior yang mereka yakini kiprahnya di partai. Baik Tomi maupun Rio sama-sama memiliki caleg yang mereka yakini akan lolos sebagai salah satu wakil rakyat. Perbedaannya hanya pada perbedaan sosok caleg dan dapilnya. Tomi membantu menjadi salah satu tim sukses bagi 2 orang caleg yang mecalonkan diri untuk DPR pusat dan DPRD Provinsi. Sementara Rio hanya membantu sebagai salah seorang caleg yang mencalonkan diri di DPRD Kota Malang.

Keduanya cukup bersemangat dalam menjadi tim sukses sebagaimana yang saya saksikan pada beberapa proses kampanye di lapangan. Rio bahkan sempat berhujan-hujan hanya untuk memberikan pengarahan di sekitar kampungnya untuk memilih calon yang ia dukung. Namun rupanya keseriusan mereka sebagai anggota tim sukses rupanya juga mendapat cibiran dari kader yang lain. Sebagaiamana yang diketahui pada pemilu legislatif 2014 lalu, mulai diberlakukan model mekanisme pemilihan yang terbuka sehingga proses persaingan tidak hanya terjadi antara caleg beda partai saja, namun juga caleg-caleg di dalam partai itu sendiri. Hal tersebut yang kemudian mulai memunculkan konflik-konflik di tubuh partai terutama di kalangan tim sukses. Sebagaimana yang dialami oleh Rio yang sempat mendapatkan diskriminasi etnisitas secara langsung dari beberapa anggota tim sukses caleg yang lain. Bak berusaha memancing emosi Rio, beberapa kader tim sukses tersebut saya amati memang kadang kerap mencibir Rio karena pergerakan politik taktisnya yang lebih handal dan cepat. Ilmu yang didapatkannya saat perkuliahan rupanya mampu ia terapkan secara sistematis pada masa pemilu legislatif 2014 dan membuat anggota tim sukses caleg lainnya ketar ketir karena saling memperebutkan jumlah suara di dapil yang sama. Namun Rio seolah cuek dan memberikan bukti nyata melalui proses kampanye yang ia galang untuk meningkatkan popularitas dan suara dari caleg yang ia dukung.

Lain halnya dengan Tomi dimana ia mesti berkeliling kampung ke kampung untuk mencari dukungan demi caleg yang ia dukung. Tomi mengaku diberikan sejumlah uang oleh caleg yang ia dukung untuk akomodasi selama ia membantu berkampanye. Bagi Tomi, meskipun jumlah uang yang diberikan pas-pas an, namun dari sana ia belajar dan mendapatkan pengalaman terutama bahwa menyakinkan seseorang untuk mencoblos caleg pilihannya tidaklah mudah. Belum lagi ketika Tomi berkeliling kampung juga kerap bertemu dengan kader anggota tim sukses caleg lain namun satu partai. Di sana konflik juga terjadi dimana Tomi mendapatkan nama buruk akibat beritaberita miring yang disebarkan oleh sesama tim sukses. Terlebih lagi membawa konteks 
etnisitas yang dimilikinya. Hal tersebut memancing emosi Tomi dan menurut penuturannya mengakibatkan perkelahian antara dia dengan kader partai dari tim sukses caleg yang berbeda.

"Ya gimana Mas, masa saya dibilang Madura yang nggak bisa dipercaya omongannya. Namanya kampanye kan mesti menonjolkan sisi baik caleg Mas. Saya sudah muter-muter keliling malah dapat info kayak gitu, ya marah saya. Apalagi pas saya samperin orangnya malah ngelunjak dan ngatain saya Mas. Ya sudah Mas, emosi saya. Akhirnya ya kelahi sama itu orang. Kalo bagi kami orang Madura Mas, harga diri itu nomor satu Mas. Kalau sudah menyangkut apa yang saya percayai dan diusik-usik ya saya marah Mas" (Wawancara Mei 2014)

Namun dari kontestasi politik selama pemilu legislatif 2014 tersebut, identitas yang dimiliki oleh masing-masing informan ternyata juga membawa beberapa kesempatan untuk eksis di dunia partai politik. Santi misalnya karena ia merupakan caleg perempuan termuda di partai, hal tersebut membuatnya mudah dikenal terutama oleh para petinggi partai. Hal tersebut yang akhirnya hingga saat ini ia manfaatkan untuk memperoleh eksistensi di partai politik. Hal yang sama juga pada Rio yang justru menjadikan identitas etnis yang ia miliki sebagai bahan kampanye di masyarakat. Bagi Rio rupanya aspek identitas minoritas yang melekat pada dirinya tersebut justru juga menjadi "senjata politik" untuk menarik simpatisan dan juga popularitas partai. Hal ini karena ia mampu untuk masuk ke dalam masyarakat minoritas langsung dan menyebutkan bahwasanya partainya merupakan partai yang majemuk dan mampu mengakomodir suara minoritas, meskipun dalam kenyataannya masih terdapat diskriminasi.

Selain itu melalui identitas minoritas yang dimiliki, masing-masing informan mampu untuk menjalin relasi dengan kader senior utamanya para petinggi di partai politik. Hal yang kemudian membuat mereka seolah mendapatkan berkah eksistensi selama pemilu legislatif. Karena mereka minoritas justru membuat mereka "berbeda" dan menjadi perhatian bagi khalayak partai. Memang masih terdapat beberapa kader yang masih menerapkan diskriminasi ras, kelas, dan jender pada anak-anak muda yang berasal dari kalangan minoritas ini. Namun, para kader senior dan juga petinggi partai juga jauh lebih mudah untuk "membedakan" mereka dengan kader yang lain. Bahkan terbukti saat ini, ketiganya masih dipercaya oleh para kader senior dan juga petinggi partai. Bagi ketiganya identitas minoritas yang mereka miliki memang mampu menjadi dua sisi mata pisau. Pada satu sisi memang mereka mendapatkan pengalaman yang kurang menyenangkan terutama karena suara/berita miring terkait identitas yang melekat pada diri mereka. Namun rupanya pada sisi yang lain, hal tersebut membuat mereka lebih dikenal dan mampu memperoleh eksistensi cepat di partai politik.

\section{Menelaah Kemajemukan di dalam Partai Politik}

Konsep multikulturalisme kerap kali dikumandangakan dalam berbagai aspek kajian di Indonesia terutama dalam hal untuk menghargai kemajemukan serta perbedaan di antara masyarakat (Suparlan, 2014; Hefner, 2007). Namun rupanya kemajemukan multi kultural yang dimiliki oleh Indonesia tidak kemudian mampu menyatukan 
masyarakatnya. Segregasi etnisitas dan kultural yang telah dibangun dan kemudian dipolitisir pada zaman kolonial Belanda rupanya masih berpengaruh pada era saat ini (Anderson,2008; Hefner, 2007). Rupanya kemajemukan Bangsa Indonesia masih tersegregasi terutama dalam konteks ras, agama, dan juga etnisitas. Hal tersebut yang kemudian disebutkan oleh Benedict Anderson bahwasanya Indonesia merupakan bangsa yang layak disebut sebagai komunitas terbayang akibat kemajemukan yang dimiliki semu dimana konsep mayoritas dan minoritas masih kuat melekat di dalamnya (2008). Lantas bagaimana telaah kontekstualisasi kemajemukan pada narasi anak-anak muda seperti Sinta, Rio, dan Tomi?

Dalam satu sisi, anak muda merupakan generasi penerus terutama dalam hal merangkai keberagaman di ranah identitas sosial politik Indonesia. Mengapa demikian? Hal ini sebagaimana yang pernah dijelaskan oleh Manheimm bahwa generasi muda akan membawa beban tanggungan dari generasi sebelumnya (2013). Ketidaksesuaian beban yang ada kerap kali diturunkan pada generasi yang lebih muda. Lantaran generasi-generasi sebelumnya juga masih mengalami proses segregasi etnisitas dan juga ras maka tak heran apabila kemudian generasi muda yang seolah mendapatkan arahan agar dapat lebih menjaga kemajemukan dalam bingkai nasionalisme kebangsaan. Masih teringat dimana konsep sila pertama mengenai konsep Ketuhanan yang sempat menjadi perdebatan antara agama mayoritas dan minoritas dimana akhirnya tercapai sebuah kesepakatan di antara para tokoh Bangsa untuk menggunakan konsep Ketuhanan Yang Maha Esa (Tirto.id). Dalam konteks perekonomian misalnya dimana generasi usia anak muda kerap kali hanya dianggap sebagai bagian konstruksi pragmatis politis (Naafs \& White, 2012). Terdapat perbedaan antara kontestasi di lapangan dengan konsep yang diyakini secara general.

Hal tersebut yang juga terjadi dalam konteks kajian kali ini dimana anak-anak muda ini didorong untuk melestarikan keberagaman kemajemukan berbangsa namun mengalami diskriminasi secara ras, kelas, dan jender. Kali ini saya memilih untuk melihat bahwasanya diskriminasi yang terjadi kepada anak-anak muda tersebut dalam 3 aspek yakni ras, kelas, dan jender. Mengapa ketiga aspek ini menjadi dominan dalam konteks diskriminasi di dalam kajian kali ini karena ketiganya merupakan identitas yang melekat pada para informan tersebut. Berasal dari ras dan kelas minoritas serta jender yang dianggap lebih lemah membuat anak-anak muda ini terjebak dalam pola diskriminasi yang sebenarnya juga terkadang mereka alami di dalam masyarakat. Partai politik yang dianggap sebagai ranah untuk ajang aktualisasi diri sekaligus sebagai proses pembentukan karakter bagi kaderkader muda justru beberapa kader di dalamnya masih terjebak dalam pola diskriminasi (Katz \& Crotty, 2014, Meiji, 2016).

Dari narasi-narasi ketiga informan tersebut terjalin dan menunjukkan bahwasanya terdapat pola diskriminasi yang secara sadar maupun tanpa sadar dilakukan oleh beberapa kader yang ada di partai tersebut. Utamanya diskriminasi dalam 3 konteks hal yakni ras, kelas, dan jender. Sebagaimana dialami oleh Rio yang merupakan anak muda keturunan etnis minoritas, Sinta yang merupakan perempuan dari kelas ekonomi bawah, maupun Tomi si "tukang parkir" yang kerap dicap meledakledak. Rupanya partai politik yang diharapkan mampu menjadi ajang untuk 
berdiskusi dan aktualisasi diri bagi para anggotanya justru masih menjadi ranah bagi kader lainnya dalam memperlihatkan diskriminasi pada anggota minoritas. Partai politik yang merupakan wadah bagi anggotanya untuk berkumpul dan mengajukan pendapat justru malah terjebak dalam pola aliran eksklusivitas dimana mereka yang berasal dari kelompok minoritas masih mendapatkan stereotype negatif.

Dalam konsepnya mengenai pendidikan yang inklusif, France menjelaskan bahwa ranahranah yang ada di masyarakat masih terjebak dalam pola eksklusivitas yang normatif (2007). Maksudnya adalah bahwa kebijakan inklusif yang diterapkan (dalam ranah pendidikan) masih terganjal adanya polapola eksklusif tersebut utamanya persoalan kelas. Hal yang juga terjadi di konteks partai politik dimana ketiga anak muda ini menjadi putaran arus diskriminasi ras, kelas, dan juga jender. Partai politik yang notabenenya seharusnya memberikan wacana-wacana mengenai pentingnya kemajemukan dalam berbangsa justru limbung dalam ranah praktek. Sebagaimana observasi dan hasil wawancara saya pada beberapa petinggi di partai tersebut bahwasanya mereka beberapa kali mengadakan diskusi ataupun workshop mengenai multikulturalisme dalam bingkai nasionalisme dan kebangsaan. Pun demikian dengan agenda partai yang menggaungkan pentingnya keberagaman dalam menjaga spirit kebhinekaan. Dalam praktek di lapangan rupanya justru mengalami malfungsi karena masih terdapat kader-kader yang melakukan diskriminasi pada anakanak muda yang berasal dari kelas minoritas.

Meskipun mengalami pola diskriminasi atau juga kekerasan simbolik dari beberapa oknum anggota partai, ketiga informan kunci ini justru semakin terpacu untuk memberikan dan membuktikan bahwasanya mereka bisa lebih baik daripada yang menggunjing. Konteks ini membawa mereka ke sebuah perubahan yang lebih pasti, sebagaimana dijelaskan oleh Ranciere tanpa melakukan "struktur penundaan" yang sifatnya pasif, ketiganya langsung mengajukan tindakan di luar logika konvensional yang seolah tanpa bertele-tele harus mengadu pada para petinggi partai namun berkarya sesuai dengan kemampuan mereka (dalam Robet,2011). Bagi Rio, Sinta, dan Tomi tidak ada lagi berduka ataupun merengek pada para petinggi partai terkait diskriminasi ras, kelas, dan jender yang mereka alami. Bagi mereka langkah pasti yang semestinya dilakukan adalah langsung beraksi di partai dengan menunjukkan kemampuan yang mereka miliki secara perlahan. Hal ini karena bagi mereka bukti otentik lebih berarti ketimbang hanya sekedar bersedih karena diskriminasi yang dialami. Melalui pembuktian tersebut pula ketiga kader ini keluar dari logika normatif konvensional yang langsung menggulingkan struktur disriminasi yang mereka alami (Robet, 2011).

\section{Kesimpulan}

Partai politik sebenarnya merupakan wadah sekaligus sarana bagi generasi muda mengembangkan diri mereka dalam aktualisasi politik sekaligus mengejawantahkan kemajemukan dalam konsep kebhinekaan. Namun sayangnya masih terdapat gap antara konteks wacana kemajemukan yang digaungkan oleh partai dengan keseharian para kader di dalamnya. Kemajemukan sebagai sebuah proses keseharian justru tertatih-tatih akibat ketidaksesuaian antara wacana partai dengan tindakan kader yang ternyata masih mendiskriminasikan beberapa kader lain, terutama bagi mereka yang berasal dari 
kelompok minoritas. Hasilnya proses diskriminasi tersebut langgeng dan melekat karena baik generasi senior maupun yang muda terlibat di dalamnya sehingga menjadi bahaya laten. Hal ini terutama terkait bagaimana diskriminasi tersebut rupanya menjadi menular pada generasi selanjutnya pada golongan minoritas seperti aspek ras, kelas, maupun jender. Hal yang semestinya dapat disingkirkan mengingat partai politik merupakan sarana demokratisasi bagi masyarakat dan membawa beban moral secara normatif.

Meskipun kader yang berasal dari kelompok minoritas tersebut mengalami diskriminasi dari anggota yang lainnya, mereka masih berusaha untuk gigih melawan hal tersebut dengan tetap berkarya secara optimal di dalam partai. Tanpa harus bersedih akibat proses diskriminasi yang mereka alami, ketiganya lebih membuktikan secara otentik di dalam kegiatan atau keseharian di partai. Hal tersebut merupakan bentuk perlawanan yang ketiganya lakukan untuk membuat partai politik lebih berkembang tanpa adanya polemik diskriminasi terhadap kelompok minoritas. Meskipun belum terlalu Nampak hasilnya, Sinta, Rio, dan Tomi percaya bahwasanya akan ada perubahan dari usaha-usaha yang nantinya telah dan akan mereka lakukan di partai politik.

\section{Daftar Pustaka}

Anderson, B. 2008. Imagined Communitites. Yogyakarta: Insist \& Pustaka Pelajar.

Banurea, R. N. 2015. Kuasa dalam Kebungkaman: Reproduksi Wacana Terhadap Perempuan Etnis Cina Korban Pemerkosaan dalam Peristiwa Mei 1998. Tesis UGM Yogyakarta.
Bertaux, D. (Ed.). 1981. Bibliography and society: the life history approach in the social sciences. London: Sage.

Coppel, C. A. 1997. Revisiting Furnivall's 'plural society': Colonial Java as a mestizo society?. Ethnic and Racial Studies, 20(3), 562-579.

France, A. 2007. Understanding youth in late modernity. McGraw-Hill Education (UK).

Hefner, R. W. 2007. POLITIK MULTIKULTURALISME-Menggugat Realitas Kebangsaan. Kanisius.

Trijono, L. 2001. Keluar dari Kemelut Maluku. Refleksi Pengalaman Praktis Bekerja untuk Perdamaian Maluku, Yogyakarta: Pustaka Pelajar.

Lay, C. 2009. Kekerasan Atas Nama Agama: Perspektif Politik. JSP (Jurnal Ilmu Sosial dan Ilmu Politik), 13(1), 1-19.

Lombard, D. 2000. Nusa Jawa: Silang Budaya, Kajian Sejarah Terpadu Bagian I aringan Asia. Jakarta: Gramedia Pustaka Utama.

Mannheim, K. 2013. Essays Sociology Knowledge (Vol. 5). Routledge.

Marijan, Kacung. 2012. Sistem Politik Indonesia, Konsolidasi Demokrasi Pasca- Orde Baru. Jakarta: Kencana.

Meiji, N. H. 2016. Pendidikan Politik Dalam Kuasa Simbolik Kajian Mengenai Dinamika Politik Anak Muda Yang Tergabung Dalam Partai Politik Di Kota Malang. Jurnal Sosiologi Pendidikan Humanis, 1(2), 103-116.

Patji, A. R. 2003. Tragedi Sampit 2001 dan Imbasnya ke Palangkaraya (Dari Konflik ke (Re) konstruksi). Jurnal Masyarakat dan Budaya, 5(2), 14-34.

Robet, R. 2011. Yang-Politis, Yang-Estetis, dan Kesetaraan Radikal, Etika Politik Jacques Ranciere. Srimulyani.net, 3153. 
Suparlan, P. 2014. Menuju masyarakat Indonesia yang multikultural. Antropologi Indonesia.

Toer, P. A. 2001. Arus Balik: Sebuah Epos Pasca Kejayaan Nusantara di Awal Abad ke-16. Jakarta: Hasta Mitra

Van Klinken, G. A. 2007. Perang kota kecil: kekerasan komunal dan demokratisasi di Indonesia. Yayasan Obor Indonesia.

White, B., \& Naafs, S. 2012. Generasi antara: refleksi tentang studi pemuda Indonesia. Jurnal Studi Pemuda, 1(2), 89-106. https://tirto.id/saat-perwakilan-dariindonesia-timur-menolak-039syariatislam039-cq7n (diakses pada tanggal 18 November 2017).

http://pdiperjuangan-jatim.com/jokowiindonesia-adalah-rumah-bagikemajemukan/ (diakses pada tanggal 18 November 2017). 